\title{
EFFECTS OF NAPHTHALENE ACETIC ACID ON YIELD ATTRIBUTES AND YIELD OF TWO VARIETIES OF RICE (ORYZA SATIVA L.)
}

\author{
AMM Golam AdAM AND NARgIS JAHAN ${ }^{1}$ \\ Department of Botany, University of Dhaka, Dhaka-1000, Bangladesh
}

Key words: Rice, Naphthalene acetic acid, Foliar application, Yield

\begin{abstract}
Effects of 100 and 200 ppm of naphthalene acetic acid (NAA) on yield attributes and yield of two varieties of rice during 2009 - 2010 Boro season were evaluated. The highest plant height was observed due to $200 \mathrm{ppm}$ in both BRRI dhan-29 $\left(\mathrm{V}_{1}\right)$ and BRRI dhan-50 $\left(\mathrm{V}_{2}\right)$. Number of tillers per plant were found to increase due to 100 ppm NAA only in BRRI dhan-29 and varied non-significantly. Yield attributes, viz. number of branches per panicle, number of grains per panicle and filled grains per panicle increased in BRRI dhan-29, following both 100 and 200 ppm NAA, whereas, most of the yield parameters decreased in BRRI dhan-50. Due to 100 and 200 ppm NAA, grain yield per plant increased by 27.67 and $6.85 \%$, respectively in BRRI dhan-29 though not statistically significant. However, in BRRI dhan-50 grain yield per plant decreased by $26.54 \%$ due to $100 \mathrm{ppm}$ and $27.67 \%$ due to $200 \mathrm{ppm}$. Out of the two concentrations $100 \mathrm{ppm}$ NAA produced better stimulation.
\end{abstract}

The use of growth regulators is considered as one of the way of increasing yield. NAA, a synthetic growth regulator has proved its potentiality that in appropriate concentration NAA affects the growth and yield of a number of plants viz. tomato (Chhonker and Singh 1959), bitter gourd (Jahan and Fattah 1991) and cowpea ( Ullah et al. 2007). Reports regarding the growth and yield aspect with NAA on cereal plants including rice are available in other countries (Misra and Sahu 1957, Chaudhuri et al.1980, Singh and Gill 1985, Grewal and Gill 1986, Muthukumar et al. 2005). In Bangladesh very limited research has been done on growth and yield aspects on cereal crops with NAA. Therefore, the present investigation was undertaken to study the effect of NAA on yield attributes and yield of two varieties of rice.

The pot experiment was conducted in the garden of the Department of Botany, University of Dhaka during the period from November, 2009 to April, 2010. Each pot (about $30 \mathrm{~cm}$ in diameter at the top) was filled with $9.0 \mathrm{~kg}$ air dried soil. Cow-dung was mixed uniformly during pot preparation and $2 \mathrm{~g}$ of gypsum was also added in each pot (equals to $444 \mathrm{~kg} / \mathrm{ha}$ ). The experiment was laid out in a randomized complete block design (RCBD) with three replications. Plant materials were collected from Bangladesh Rice Research Institute (BRRI), Joydebpur, Gazipur. BRRI dhan-29 is a high yielding variety released in 1994 and BRRI dhan-50 is an aromatic variety released in 2008 . Seeds were sterilized by $0.5 \%$ calcium hypochlorite solution and were sown on November 7, 2009. Seedlings were transplanted to pots at 5- leaf stage at 36 days after sowing. Five hills were placed in each pot, each hill containing one seedling. Thinning was done in such way that a healthy seedling of uniform size and vigour was allowed to grow. Irrigation was done as per necessity. Weeding was done twice on 25 and 45 day after transplanting (DAT). Split applications of urea were applied twice at the rate of $1 \mathrm{~g}$ per pot (equals to $222 \mathrm{~kg} / \mathrm{ha}$ ) at $20 \mathrm{DAT}$ and at $50 \mathrm{DAT}$. There were three treatments as follows; $\mathrm{T}_{0}=$ distilled water (Control), $\mathrm{T}_{1}=100$ ppm NAA and $\mathrm{T}_{2}=200$ ppm NAA.

Treatments were applied as foliar spray at 57 DAT. Plant height, number of tillers per plant, number of panicles per plant, length of panicle, number of branches per panicle, total grains per panicle, filled grains per panicle, per cent un-filled grains per panicle and 1000-grain weight were recorded after harvest. Yield per plant was calculated according to the formula of ICRISAT

${ }^{1}$ Corresponding author: < imuttaqi@yahoo.com>. 
(1992). Harvest index was also calculated. Data were analyzed statistically (Steel and Torrie 1960) and treatment means were compared by LSD test at 5\% level of significance.

Results presented in Table 1 showed that at harvest plant height was non-significantly affected by both the treatments and the longest plants were recorded from $T_{2}$ treatment. In case of $V_{1}$, plant height was found to increase only due to $T_{2}$ treatment whereas, in $V_{2}$ plant height increased due to both the treatments. Akter (2010) reported both increase and decrease in plant height of maize following NAA application. Yield and all the yield attributes except 1000-grain weight in both the rice varieties were non-significantly affected by NAA treatments (Table I). Number of tillers per plant has an indirect effect on yield, but it has a positive effect via the number of panicles per plant. Number of tillers per plant and number of panicles per plant decreased due to both the treatments. However, in case of interaction, number of tillers per plant and number of panicles per plant increased by 30.38 and $17.34 \%$, respectively following $T_{1}$ treatment in the variety $V_{1}$. Similar results of increases in number of ear bearing tillers following NAA application were reported by Singh and Gill (1985) on wheat and barley, Chaudhuri et al. (1980) and Grewal and Gill (1986) in rice. Akter (2010) found increase in number of cob per plant due to NAA treatment in maize; however, Misra and Sahu (1957) reported decrease in number of panicles per plant following NAA application in rice.

Table 1. Effect of NAA on yield attributes and yield of BRRI dhan-29 $\left(V_{1}\right)$ and BRRI dhan-50 $\left(V_{2}\right)$ harvest. $n=3$.

\begin{tabular}{|c|c|c|c|c|c|c|c|c|c|c|c|}
\hline Treatments & $\begin{array}{l}\text { Plant } \\
\text { height } \\
(\mathrm{cm})\end{array}$ & $\begin{array}{c}\text { No. of } \\
\text { tillers/ } \\
\text { plant }\end{array}$ & $\begin{array}{c}\text { No. of } \\
\text { pani- } \\
\text { cles/ } \\
\text { plant }\end{array}$ & $\begin{array}{l}\text { Length } \\
\text { of pani- } \\
\text { cle }(\mathrm{cm})\end{array}$ & $\begin{array}{c}\text { No. of } \\
\text { branches } \\
\text { /panicle }\end{array}$ & $\begin{array}{c}\text { Total } \\
\text { grains/ } \\
\text { panicle }\end{array}$ & $\begin{array}{c}\text { Filled } \\
\text { grains/ } \\
\text { panicle }\end{array}$ & $\begin{array}{c}\% \text { of } \\
\text { unfilled } \\
\text { grains/ } \\
\text { panicle }\end{array}$ & $\begin{array}{l}\text { 1000- } \\
\text { grain } \\
\text { weight } \\
\text { (g) }\end{array}$ & $\begin{array}{c}\text { Yield/ } \\
\text { plant } \\
\text { (g) }\end{array}$ & $\begin{array}{l}\text { Harvest } \\
\text { index (\%) }\end{array}$ \\
\hline \multicolumn{12}{|c|}{ Mean effect } \\
\hline $\mathrm{T}_{0}$ & 78.42 & 8.67 & 8.50 & 20.68 & 9.30 & 110.38 & 101.92 & 7.89 & $18.84 \mathrm{a}$ & 15.96 & 55.15 \\
\hline $\mathrm{T}_{1}$ & 78.70 & 8.50 & 8.00 & 21.10 & 9.85 & 115.35 & 106.89 & 7.23 & $18.31 \mathrm{a}$ & 16.06 & 49.18 \\
\hline $\mathrm{T}_{2}$ & 80.42 & 7.83 & 7.83 & 20.94 & 9.65 & 113.58 & 105.46 & 7.30 & $17.58 \mathrm{~b}$ & 14.30 & 47.24 \\
\hline LSD 0.05 & NS & NS & NS & NS & NS & NS & NS & NS & 0.403 & NS & NS \\
\hline \multicolumn{12}{|c|}{ Interaction effect } \\
\hline $\mathrm{V}_{1} \mathrm{~T}_{0}$ & 79.77 & 7.67 & 7.67 & 21.97 & 9.60 & 115.16 & 105.12 & 9.16 & $19.96 \mathrm{a}$ & 16.01 & 54.34 \\
\hline $\mathrm{V}_{1} \mathrm{~T}_{1}$ & 79.33 & 10.0 & 9.00 & 22.42 & 10.10 & 126.46 & 115.78 & 8.51 & $19.58 \mathrm{a}$ & 20.44 & 54.65 \\
\hline $\mathrm{V}_{1} \mathrm{~T}_{2}$ & 82.33 & 7.33 & 7.33 & 21.85 & 9.70 & 133.76 & 124.91 & 6.62 & $18.41 \mathrm{~b}$ & 17.11 & 52.12 \\
\hline $\mathrm{V}_{2} \mathrm{~T}_{0}$ & 77.07 & 9.67 & 9.33 & 19.38 & 9.00 & 105.59 & 98.71 & 6.62 & $17.71 \mathrm{c}$ & 15.90 & 55.97 \\
\hline $\mathrm{V}_{2} \mathrm{~T}_{1}$ & 78.07 & 7.00 & 7.00 & 19.77 & 9.60 & 104.24 & 98.00 & 5.94 & $17.04 \mathrm{~d}$ & 11.68 & 43.71 \\
\hline $\mathrm{V}_{2} \mathrm{~T}_{2}$ & 78.50 & 8.33 & 8.33 & 20.02 & 9.60 & 93.41 & 86.00 & 7.98 & $16.42 \mathrm{e}$ & 11.50 & 42.35 \\
\hline LSD 0.05 & NS & NS & NS & NS & NS & NS & NS & NS & 0.403 & NS & NS \\
\hline
\end{tabular}

Mean followed by same letter do not differ significantly at $5 \%$ level.

Results also showed that except \% of un-filled grains per panicle length of panicle, number of branches per panicle, total grains per panicle and filled grains per panicle increased due to both the treatments. In case of $V_{1}$, length of panicle increased due to $T_{1}$ and decreased due to $T_{2}$, whereas, in $\mathrm{V}_{2}$ length of panicle increased due to both the treatments. Similar results of increase have also been reported in maize (Akter 2010). Dasgupta (1975) obtained reduced pod length with higher concentrations of NAA on groundnut. Irrespective of treatments, number of branches per panicle, total grains per panicle and filled grains per panicle increased, whereas, $\%$ of un-filled grains per panicle decreased in the variety $V_{1}$. But all these yield parameters except number of branches per panicle decreased following both the treatments, whereas, \% of un-filled grains per panicle increased due to $T_{2}$ treatment in the variety $V_{2}$. Reports regarding increase in number of grains per 
panicle are in conformity with those of other workers in various plants viz. rice (Misra and Sahu 1957, Chaudhuri et al.1980 and Grewal and Gill 1986), wheat and barley (Singh and Gill 1985) and maize (Akter 2010).

Treatment means revealed that 1000-grain weight decreased following both the treatments and the decreases were significant. However, 1000-grain weight also decreased due to both the treatments in both the varieties and the decreases were significant except $T_{1}$ treatment in $V_{1}$. The weight of 1000-grain depends on size and filling of the grains. The reduction in weight of 1000grain in all probability was due to less accumulation of photosynthate in the grain. Reports regarding both increase and decrease in 1000-grain weight were recorded by different workers. The results are in conformity with the findings of Singh et al. (1972) on pea and Ullah et al. (2007) on cowpea who reported that 1000-grain weight decreased due to higher concentration of NAA.

Results also indicate that grain yield per plant increased due to $T_{1}$ treatment but decreased due to $T_{2}$ treatment. However, grain yield per plant increased due to both the treatments in $V_{1}$, whereas, decreased in $V_{2}$. Grain yield due to $T_{1}$ increased by $27.67 \%$ in the variety $V_{1}$ but decreased by $26.54 \%$ in the variety $V_{2}$. Due to $T_{2}$ treatment, the increase in the yield was $6.85 \%$ in $\mathrm{V}_{1}$, whereas, the decrease was $27.67 \%$ in $\mathrm{V}_{2}$. Similar results of increase in grain yield were reported by many investigators viz. Chaudhuri et al. (1980), Sahu and Murty (1981) and Grewal and Gill (1985) in rice, Tulsa Ram et al. (1997) in sorghum, Muthukumar et al. (2005) in baby corn and Akter (2010) in maize. Decreased grain yield was also reported by Borkar et al. (1991) in cowpea. Harvest index decreased following both the treatments. Harvest index was found to increase due to $T_{1}$ and decrease due to $T_{2}$ in $V_{1}$, but decreased due to both the treatments in $V_{2}$. Harvest index varied from 52.12 - 54.65\% in $\mathrm{V}_{1}$ and from $42.35-55.97 \%$ in $\mathrm{V}_{2}$ and also varied non-significantly. The value of harvest index varied with the fraction of biological yield being transferred to the seed.

Findings of this study indicated that the increase in yield following both the treatments in the variety $\mathrm{V}_{1}$ could be due to the combined effect of increases in almost all the reproductive parameters and also decrease in per cent of un-filled grains per panicle. Moreover, increase in yield per plant achieved with $\mathrm{T}_{1}$ treatment was due to increased assimilative area and as a result more photosynthesis throughout the growth period. Thus, 100 ppm NAA proved to be more stimulative. The results also indicate that NAA has both stimulatory and inhibitory effect on different yield parameters, and it depends on several factors including the varietal difference and concentration of the chemical. The results are consistent with the view that the plant growth regulators can exert quite different effects in different plants (Ridge 1991). Thus, analyses of data indicate that, out of the two concentrations of NAA, $100 \mathrm{ppm}$ NAA produced better stimulations in the variety $\mathrm{V}_{1}$ but the magnitude of effect was different.

\section{References}

Akter R 2010. Effect of Naphthalene acetic acid (NAA) on growth, physiological and biochemical responses and yield attributes of maize (Zea mays L. var. Pacific 283). M. S. Thesis. Department of Botany, University of Dhaka, Dhaka.

Borkar DH, AD Mattebhelkar, MVDR Kene and TR Bagde 1991. Effect of seed treatment with different plant growth regulators on growth and yield of cowpea (Vigna sinensis Savi). J. Soil Crops 1(2): $165-$ 168.

Chaudhuri D, P Basuchaudhuri and DKD Gupta 1980. Effect of growth substances on growth and yield of rice. Ind. Agriculturist 24: 169-175.

Chhonkar VS and SN Singh 1959. Effect of Naphthalene acetic acid on growth, quality and yield of tomato. Ind. J. Hort. 16(4): 236-242. 
Dasgupta DK 1975. Effect of NAA on crop plants in sierra leoue. I. Groundnut Expl. Agril. II: 209-213.

Grewal HS and HS Gill 1986. Influence of NAA and Nitrogen on the growth and yield of late planted paddy (Oryza sativa L.). J. Agril. Sci. 106: 37-40.

ICRISAT 1992. Research Planning and Data Handling. Diwakar, B. and D.L. Oswalt. Int. Crop Res. Inst. For Semi-arid Tropics. Patancheru, Andhra Pradesh. pp. 67.

Jahan N and QA Fattah 1991. Effect of foliar treatments of NAA and IBA on reproductive and yield parameters of bitter gourd (Momordica charantia L.). Dhaka Univ. Stud. Part E. Biol. Sci. 6(1): 69-71.

Misra G and G Sahu 1957. Physiology of growth and reproduction in rice 1. Effect of plant growth substances on an early variety. Bull. Torrey Bot. Club 86(6): 442-449.

Muthukumar VB, K Velayudham and N Thavaprakaash 2005. Growth and yield of baby corn (Zea mays L.) as influenced by PGRs and different time of Nitrogen application. Res. J. Agril. Biol. Sci. 1(4): 303-307.

Ridge I 1991. Plant Physiology. Open University, Hodder and Stoghton, Kent.

Sahu G and KS Murty 1981. Note of the effect of foliar spray of hormone compounds and micronutrient mixtures on yield of rice. Ind. J. Agril. Sci. 51(3): 196-198.

Singh H and HS Gill 1985. Effect of foliar spray of NAA on the growth and yield of late sown wheat and barley. Ind. J. Eco. 12: 267-272.

Singh T, BV Sinhgbad and BS Panwar 1972. Effect of pre-sowing treatments with phytohormones on the yield of pea (Pisum sativum). Ind. J. Agril. Res. 6(4): 279-284.

Steel RGD and JH Torrie 1960. Principles and procedures of statistics. McGraw- Hill, New York.

Tulsa-Ram, AL Maliand and AK Vas 1997. Economics of dry sowing method of fertilizer application and growth regulator application in sorghum. Crop. Res. 13(3): 675-676.

Ullah MJ, QA Fatttah and F Hossain 2007. Response of growth, yield attributes and yield to the application of KNap and NAA in cowpea (Vigna unguiculata (L.) Walp.). Bangladesh J. Bot. 36(2): 127-132.

(Manuscript received on 23 March, 2011; revised on 2 May, 2011) 